\title{
PREVALENCE OF HEPATITIS B AND C VIRUS SEROPOSITIVITY AMONG TRIBAL AND NON-TRIBAL VOLUNTARY BLOOD DONORS OF RANGAMATI, BANGLADESH
}

\author{
Dewan G.*
}

\begin{abstract}
INTRODUCTION: Prevalence of hepatitis B and C virus seropositivity is not defined among blood donors of Rangamati district of Bangladesh. This region is mainly inhabited by tribal population of multiethnic stocks. Government policy formulation for tribal health is lacking data on this issue among tribal population of Bangladesh.

MATERIALS AND METHODS: A retrospective study on eight years data from 2005 to 2013 carried out to define hepatitis $\mathrm{B}$ and $\mathrm{C}$ virus related seropositivity among tribal and non-tribal voluntary blood donors in Rangamati General Hospital.

RESULTS: A total of 4974 unit of blood were screened during this period. Of them 2760 unit were from tribal and 2214 unit from non-tribal donors. Result shows there is higher prevalence of hepatitis B seropositivity among tribal donors $(n=100)$ compared to non-tribal $(n=26)$. The prevalence rate for hepatitis B virus was $3.62 \%$ for tribal population and $1.17 \%$ for non-tribal population. This difference was statistically significant $(p<0.0001)$. Hepatitis $\mathrm{C}$ seropositivity was low in both groups.
\end{abstract}

CONCLUSION: In Rangamati tribal population bear significantly higher burden of hepatitis B infection than non-tribal population.

KEYWORDS: Hepatitis B, Hepatitis C, Blood transfusion, Tribal, Bangladesh.

\footnotetext{
* Consultant, Department of Internal Medicine, Rangamati General Hospital, Rangamati, Bangladesh
}

\author{
For Correspondence \\ Dr. Gourab Dewan, \\ Consultant, \\ Department of Internal Medicine, \\ Rangamati General Hospital, \\ Rangamati, Bangladesh \\ E-mail: gourab.dewan@yahoo.com
}




\section{INTRODUCTION}

Hepatitis B (HBV) and hepatitis C (HCV) virus related infection are among the commonest transfusion transmitted diseases worldwide. The situation is also similar in Bangladesh. ${ }^{1}$ Since introduction of safe blood transfusion act in 2002 all institutes with transfusion facilities mandatorily carry out screening for hepatitis B and hepatitis C viruses besides human immune deficiency virus, syphilis serology and malaria parasite screening. ${ }^{2}$

The current health policy of Bangladesh included the issue of tribal health for the first time. ${ }^{3}$ Out of 144 million populations in Bangladesh tribal population consists of two million. Majority being in malaria stricken three hill districts situated on south eastern part near India and Myanmar. ${ }^{4}$ But the program has hit a deadlock as no sufficient data exist regarding health problems of tribal population except that on malaria which has well established national control program. Priority areas are yet to be determined for this tribal health program. ${ }^{3}$ Residence in remote areas in scattered groups makes data collection difficult from tribal subjects. Health seeking behavior and practice among tribal groups differs from general population and often they are deprived of modern medicine. ${ }^{5}$

Since the introduction of screening program by Government of Bangladesh various studies have been carried out to estimate hepatitis virus seroprevalence . Almost all studies have been carried out in capital of Dhaka either in tertiary level hospital or voluntary private blood donor institution. ${ }^{6-9}$ All data reflect that of non-tribal population.

Therefore this current study was undertaken to estimate prevalence of this common health care related problem among tribal population and compare the result with national data and non-tribal people of Rangamati to estimate its public health urgency.

\section{MATERIALS AND METHODS}

Rangamati district was the place of study. It is the largest and one of least developed districts of Bangladesh having border with both India and Myanmar. Tribal population of different ethnic groups reside here and also non-tribal general Bengali population. Presence of hills, dense forest and river makes Rangamati one of the remotest areas of Bangladesh.

A retrospective study carried out in Rangamati General Hospital (RGH), blood transfusion department. This is the only Government center in Rangamati which is equipped for blood transfusion. Blood transfusion started here in 1998. Record registers of blood sample screened in past years were checked. Five volumes were available dating from $21^{\text {th }}$ August of 2005. Data were collected up to $20^{\text {th }}$ August 2013. Each year's data for individual donor was examined and the frequency of hepatitis B \& C virus seropositivity recorded. Donors were divided into tribal and non-tribal group. Whereas tribal population was subdivided into ethnic groups they belonged.

Data analyzed in SPSS version 21. Frequency of HBV and HCV seropositivity was recorded and comparison was done among tribal and non-tribal population. Any level of significance was tested with chi-square test or Fisher's exact test as applicable.Level of significance defined as $p \leq 0.05$.

\section{RESULTS}

From a total of 4974 people screened over eight years; 4674 $(93.96 \%)$ were male and $300(6.03 \%)$ were female. Tribal were $2760(55.48 \%)$ and nontribal 2214 (44.51\%). Ten different tribal groups had representation in this case series. Chakma community was the predominant tribal group $(n=2475)$. Mean age of population studied was $27.30 \pm 6.83$ years. The sex, ethnic characteristics of the population given in Table 1.

Table 1: Ethnic and sex distribution of blood donors at Rangamati General Hospital

\begin{tabular}{|l|c|c|c|}
\hline Study population & Male & Female & Total \\
\hline Tribal & & & \\
\hline Chakma & 2330 & 145 & 2475 \\
\hline Marma & 104 & 4 & 108 \\
\hline Tripura & 93 & 5 & 98 \\
\hline Tanchangya & 47 & 9 & 56 \\
\hline Gurkha & 7 & 2 & 9 \\
\hline Pankhua & 5 & 1 & 6 \\
\hline Assam & 5 & - & 5 \\
\hline Others & 1 & 2 & 3 \\
\hline Non-tribal & 2082 & 132 & 2214 \\
\hline Total $(N)$ & 4674 & 300 & 4974 \\
\hline
\end{tabular}

There were 142 units of blood discarded due to various transfusion transmitted disease. Of them 135 (95.07\%) unit were positive for hepatitis $\mathrm{B}$ or $\mathrm{C}$ viruses. Among them 107 sample were from tribal donor and 28 from non-tribal donor. Data of these 135 cases given in Table 2 .

Table 2: Hepatitis $B$ and $C$ seropositive cases

\begin{tabular}{|l|c|c|c|c|c|}
\hline \multirow{2}{*}{$\begin{array}{c}\text { Study } \\
\text { group }\end{array}$} & \multirow{2}{*}{$\begin{array}{c}\text { Total } \\
\text { population }\end{array}$} & \multicolumn{2}{c|}{ HBV } & \multicolumn{2}{c|}{ HCV } \\
\cline { 3 - 6 } & Positive & P. (\%) & Positive & P. (\%) \\
\hline Tribal & 2760 & 100 & $3.62 \%$ & 7 & $0.25 \%$ \\
\hline Non-tribal & 2214 & 26 & $1.17 \%$ & 2 & $0.09 \%$ \\
\hline Overall & 4974 & 126 & $2.53 \%$ & 9 & $0.18 \%$ \\
\hline
\end{tabular}


One hundred and twenty six samples were positive for hepatitis B surface antigen (HBsAg) while only 9 positive for $\mathrm{HCV}$. Among HBV positive cases 100 were of tribal origin and 26 non-tribal origin. Among HBV positive tribal samples 96 were male and 4 female while in 26 non-tribal sample 24 male and 2 female. Among $9 \mathrm{HCV}$ seropositive samples 7 from tribal and 2 from non-tribal. All HCV positive cases were male.

Prevalence of seropositivity for HBV was $2.53 \%$ and for HCV $0.18 \%$ in current study population. HBV seropositivity was $1.17 \%(n=26)$ for non-tribal and $3.62 \%(n=100)$ for Tribal. The higher frequency of HBsAg seropositivity among tribal population was statistically significant compared to non-tribal community $(p<0.0001)$.

Table 3: Distribution of seropositive cases by tribal groups

\begin{tabular}{|c|c|c|c|c|c|c|c|c|c|}
\hline \multirow{3}{*}{ Seropositive } & \multicolumn{2}{|c|}{ Chakma } & \multicolumn{2}{|c|}{ Marma } & \multicolumn{2}{|c|}{ Tripura } & \multicolumn{2}{|c|}{ Tanchangya } & \multirow{3}{*}{ Total } \\
\hline & M & $\mathbf{F}$ & M & $\mathbf{F}$ & M & $\mathbf{F}$ & M & $\mathbf{F}$ & \\
\hline & \multicolumn{2}{|c|}{$(n=97)$} & \multicolumn{2}{|c|}{$(n=2)$} & \multicolumn{2}{|c|}{$(n=3)$} & \multicolumn{2}{|c|}{$(n=5)$} & \\
\hline HBsAg & 89 & 3 & 1 & - & 3 & - & 3 & 1 & 100 \\
\hline $\mathrm{HCV}$ & 5 & - & 1 & - & - & - & 1 & - & 7 \\
\hline
\end{tabular}

HBsAg hepatitis B surface antigen, $\mathrm{HCV}$ hepatitis $\mathrm{C}$ virus, $\mathrm{M}$ male, $\mathrm{F}$ female. The distribution of $\mathrm{HBV}$ and $\mathrm{HCV}$ seropositivity by tribal ethnicity is presented in Table 3 . It shows Chakma community has the most seropositive cases. Year wise HBV positive cases presented in Table 4. There was no significant rise or drop in positivity rate among the two study group.

Table 4: Hepatitis B seropositive cases year wise (21 ${ }^{\text {st }}$ August 2005 to $20^{\text {th }}$ August 2013)

\begin{tabular}{|c|c|c|c|c|c|c|c|c|c|}
\hline Study population & 2005 & 2006 & 2007 & 2008 & 2009 & 2010 & 2011 & 2012 & 2012 \\
\hline $\begin{array}{c}\text { Tribal } \\
(n=100)\end{array}$ & 7 & 5 & 20 & 14 & 8 & 5 & 10 & 18 & 13 \\
\hline $\begin{array}{c}\text { Non-tribal } \\
(n=26)\end{array}$ & 2 & 2 & 10 & 3 & 4 & 1 & 0 & 3 & 1 \\
\hline
\end{tabular}

The prevalence of HCV was not so different among study groups. It was $0.25 \%$ for tribal and $0.09 \%$ for non-tribal population $(p \geq 0.3)$.

\section{DISCUSSION}

The high frequency of HBsAg seropositivity $(n=126)$ in 142 discarded sample observed in current study was consistent with the result of previous studies done in Bangladesh. ${ }^{6-9}$ National data of 9 years ranks $\mathrm{HBV}$ infection as the commonest transfusion transmitted disease in Bangladesh . During 2001 to 2009 period 19567 units of blood were positive for HBV among 1866420 unit blood screened. This figure states $68 \%$ of transfusion transmitted disease detected during this period in Bangladesh were due to HBV. ${ }^{1}$ But in Rangamati HBsAg seropositivity rate was $88.73 \%$, higher than national data.

Government data of 9 year (2001 to 2009) show a seroprevelance of $1.04 \%$ for HBsAg among voluntary blood donors. ${ }^{1}$ Whereas in three separate institution based studies the prevalence ranged from 1.38 to $2.19 \% .{ }^{7-9}$ In Rangamati district overall HBsAg seropositivity was $2.53 \%$. Comparing the two study population it was $1.17 \%$ for non-tribal and $3.62 \%$ for tribal.

The seropositivity rate among non-tribal subjects is within the observed value nationally. The national data has very little contribution from tribal population and mainly consists of non-tribal community. So the non-tribal population in Rangamati shows HBV seroprevalence consistent with national data.

Despite being very few in number the tribal community of Rangamati has a higher hepatitis B seroprevalence. This need to be taken seriously by the tribal health policy makers in Bangladesh health service. It appears that positivity rate is stable throughout the study years (Table 3). Blood transfusion started in RGH in 1998 and screening of blood is being carried out since then. So transfusion related transmission is not the explanation for this higher value. Intravenous drug abuse is uncommon among tribal population. So most probable explanation of such higher seropositivity is continued transplacental transmission and subsequent sexual transmission. Interracial marriage with non-tribal population is not accepted social norm among tribal. That is why it is likely that this continued transmission is carried on within tribal population. Study among general tribal population and pregnant tribal women may provide more information about this hypothesis.

Difference in prevalence of HBV seropositivity and risk of infection on basis of ethnicity has been observed in studies in Indonesia \& UK. ${ }^{11,12}$ In Jakarta of Indonesia Chinese ethnicity conferred 3 times higher risk of HBsAg infection than Malayan ethnicity. In Birmingham of UK HBsAg positivity was more among African, Pakistani and non-British whites compared to native English. Variable immunologic response is thought to be the underlying explanation for ethnic difference in seroprevalence. ${ }^{11}$ Our study finding is similar to the mentioned studies. Whereas in china there was no significant risk associated with ethnicity.

Hepatitis C seropositivity $(0.18 \%)$ in current study was very low compared to $\mathrm{B}$ virus infection. National data also show that the prevalence of $\mathrm{C}$ virus infection is much lower (0.11\%) in Bangladesh. ${ }^{1}$ So the HCV seropositivity in Rangamati is also consistent with national data. The difference in 
prevalence of $\mathrm{HCV}$ seropositivity among the two study groups was not significant.

Only 4 of the 10 participating tribal ethnic group tested positive for TTD's. But the paucity in 6 tribal groups explainable by their low sample size. The Chakma community being the largest ethnic group has the highest representation here and also higher frequency of seropositivity.

\section{CONCLUSION}

Hepatitis B seroprevalence among tribal blood donor of Rangamati differs with the national data which consists mostly of non-tribal population. The data suggests the need for estimation of hepatitis B virus prevalence in general tribal population of Rangamati. As a focal point source they carry higher risk of disease transmission and therefore morbidity in comparison to general non-tribal population.

\section{CONFLICT OF INTEREST}

The author declares that he has no conflict of interest.

\section{REFERENCES}

1. Directorate General of Health Services, Bangladesh (2010) Health bulletin: Safe blood transfusion. [Internet] 2010 [cited 25 May 2013]. Available from http://en.dghs.gov.bd/index.php? option $=$ com_docman\&task $=d o c \_d o w n l o a d \& g i d=42 \&$ Itemid $=$ $30 \&$ lang $=$ en.

2. Islam MB. Blood transfusion services in Bangladesh.Asian J Transfus Sci.2009; 3(2): 108-110.

3. Bangladesh. Ministry of Health \& Family Welfare. Tribal/ethnic health population and nutrition plan for the health, population and nutrition sector development program (HPNSDP) 2011 to 2016. Dhaka: 2011
4. World Directory of Minorities and Indigenous Peoples. Bangladesh overview [Internet] 2011[Cited 25 May 2013]. Available from: http://www.minorityrights. org/?lid $=5632$.

5. Rahman SA, Kielmann T, McPake B, Normand CJ, Healthcareseeking behaviour among the tribal people of Bangladesh: can the current health system really meet their needs? J Health Popul Nutr. 2012; 30(3):353-365

6. Habibullah MM, Khatun H, Khatun A, Rabbi FJ, Seroprevalance of anti-HCV among voluntary blood donors. Bangladesh J Med Microbiol. 2009; 03 (01): 37-39

7. Chowdhury FS, Begum HA, Adnan SD, Hoque MM, Hossain MZ, Siddiqui MAE. Study on screening tests among the blood donors in Dhaka medical college hospital, Bangladesh. J Dhaka Med Coll. 2010; 19(1):16-18.

8. Saha SK, Banik RK, Saha MR, Habibullah MM, Al-Mahtab M. Prevalence of transfusion transmitted infection in healthy blood donors in Sir Salimullah medical college Dhaka, Bangladesh. Euroasian Journal of Hepato-Gastroenterology. 2011; 1(2): 68-70.

9. Ahmed MU, Begum HA, Hossain T, Chakraborty P. Incidence of Common transfusion transmitted diseases among blood donors. JAFMC Bangladesh. 2009; 5 (1): 4-6

10. Akbar N, Basu B, Mulyanto T, Garabrant DH, Sulaiman A, Noer HMS. Ethnicity, socioeconomic status, transfusions and risk of hepatitis Band hepatitis $C$ infection. $J$ Gastroenterol and Hepatol. 1997; 12 (11):752- 57

11. Caley M, Fowler T, Greatrex S, Wood A. Differences in hepatitis $B$ infection rate between ethnic groups in antenatal women in Birmingham, United Kingdom, may 2004 to december 2008. Euro Surveill. 2012,17(30): 202-28.

12. Zhang H, Qingmei Li, Sun J, Wang $C$, Gu Q, Feng $X, D u B$, Wang W, Shi XD, Zhang S, Li W, Jiang Y, Feng J, He S, NiuJ. Seroprevalence and risk factors for hepatitis $B$ infection in an adult population in northeast china. Int J Med Sci. 2011; 8(4):321-31 